\title{
Trophic linkages between grazers and ultraplankton within the microbial food web in subtropical coastal waters
}

\author{
Bingzhang Chen ${ }^{1}$, Hongbin Liu ${ }^{1,2, *}$ \\ ${ }^{1}$ Atmospheric, Marine, and Coastal Environment (AMCE) Program and ${ }^{2}$ Department of Biology, \\ Hong Kong University of Science and Technology, Clear Water Bay, Hong Kong SAR
}

\begin{abstract}
To investigate the trophic linkages among different micrograzers and their preys and the possible occurrence of trophic cascades within the microbial food web, we combined the dilution technique and size-fractionation methods to monitor the grazing rates of different grazer assemblages on various ultraphytoplankton cells in subtropical waters. The mortality rates of Synechococcus and picophytoeukaryotes $(<2 \mu \mathrm{m})$ were often higher in dilution experiments set up with $5 \mu \mathrm{m}$ prefiltered seawater (containing only heterotrophic nanoflagellates [HNFs]) than in the $<20 \mu \mathrm{m}$ treatments (including both HNFs and small ciliates), indicating the effect of trophic cascading. In addition, similar grazing rates on Synechococcus and picophytoeukaryotes can be well related to the biomass of HNFs but not to that of total grazers. Growth and grazing rates of Synechococcus and picophytoeukaryotes mostly fell to a 1:1 relationship, suggesting grazing was the major loss pathway for picophytoplankton. The trophic linkages of micrograzers and their preys in coastal waters do not appear to differ substantially from those observed in open oceans.
\end{abstract}

KEY WORDS: Ultraplankton · Heterotrophic flagellates · Trophic cascades Resale or republication not permitted without written consent of the publisher

\section{INTRODUCTION}

Microzooplankton are the dominant herbivores and nutrient recyclers in marine ecosystems (Calbet \& Landry 2004). In the majority of the herbivory studies, microzooplankton typically refer to all grazers smaller than $200 \mu \mathrm{m}$, including both protozoan and metazoan microzooplankton $(20$ to $200 \mu \mathrm{m})$ and heterotrophic (HNFs) and mixotrophic nanoflagellates (2 to $20 \mu \mathrm{m}$ ). The importance of nanoflagellates as major grazers of bacterioplankton and picocyanobacteria has been highlighted in marine environments (Caron et al. 1991, Ichinotsuka et al. 2006, Unrein et al. 2007).

It has now been increasingly recognized that multiple compartments of microzooplankton can exist within the marine microbial food web (Wikner \& Hagstrom 1988, Calbet et al. 2008, Chen et al. 2009a), and trophic cascades could occur if a third trophic level grazer feeds significantly on a second trophic level grazer (herbivore or bacterivore) and therefore the grazing pressure on the basal trophic level (phytoplankton or bacteria) would be reduced (Zöllner et al. 2009). Past studies often focused on bacteria or cyanobacteria as the basal trophic level. However, picophytoeukaryotes (PP) and nanophytoeukaryotes (NP) can be as important as, if not more important than, cyanobacteria in marine ecosystems, especially in mesotrophic waters, in terms of biomass and primary production (Worden et al. 2004).

Size plays an important role in shaping and constructing trophic linkages within the microbial food web, especially in determining predator-prey relationships. Predators are usually larger than preys in marine ecosystems except some dinoflagellates which may ingest preys larger than their own sizes (Hansen et al. 1994). Therefore, size fractionation is the method often used to address trophic interactions by removing some large grazers, using a filter of a given pore size (e.g. 
Wikner \& Hagstrom 1988). However, as grazers contribute substantially to nutrient recycling especially in oligotrophic marine ecosystems, removing grazers slows down the nutrient recycling rate, and subsequently the growth rate of the preys (phytoplankton and bacteria) would be limited in the absence of grazers, which is a usual problem in applying the size-fractionation method. As the process of size fractionation may break some delicate phytoplankton cells, the preys under investigation are usually limited to phototrophic or heterotrophic bacteria (e.g. Calbet et al. 2001).

Traditional modelers often limit the number of phytoplankton and microzooplankton boxes to be only 1 or 2 (large versus small cells). Although the need to set up size based food web models is well recognized, modelers often treat grazing mortality of different sized phytoplankton as size independent, reflecting a limited understanding of trophic linkages between grazers and their prey (e.g. Armstrong 1994). Although various feeding relationships can be observed in lab cultures isolated from marine waters (Christaki et al. 1999, 2005, Jeong et al. 2008), the real trophic interactions in situ could be quite different from lab observations. For example, marine copepods can feed on nanoplankton prey in lab environments (Frost 1972), but field experiments often show that their grazing impact on nanoplankton is negligible (Liu et al. 2005).

The dilution technique (Landry \& Hassett 1982) is a widely accepted approach to accurately estimate microzooplankton grazing rates on phytoplankton, with constant growth of phytoplankton maintained by nutrient additions. In addition, the dilution technique when combined with various tools, such as microscopic, flow cytometric, and pigment analysis, allows different phytoplankton groups to be assessed to separate phytoplankton taxa (Strom et al. 2007, Landry et al. 2008, Chen et al. 2009b). Our objective is to combine the dilution technique with the size-fractionation method to investigate the trophic linkages among different micrograzers and their preys by sequentially removing grazers of different sizes and accurately measure grazing rates of different grazer assemblages on various groups of ultraphytoplankton identified by flow cytometry (FCM).

\section{MATERIALS AND METHODS}

We conducted 6 size-fractionated dilution experiments: 5 at a coastal site (Stn PM7) east of Hong Kong (in April, May, June, July, and December of 2007) and 1 at an oligotrophic site (Y16) in the South China Sea (SCS) on September 5, 2007 (Fig. 1). The protocol of dilution experiments is based on Landry's work (1993) and has been described in detail by Chen et al.

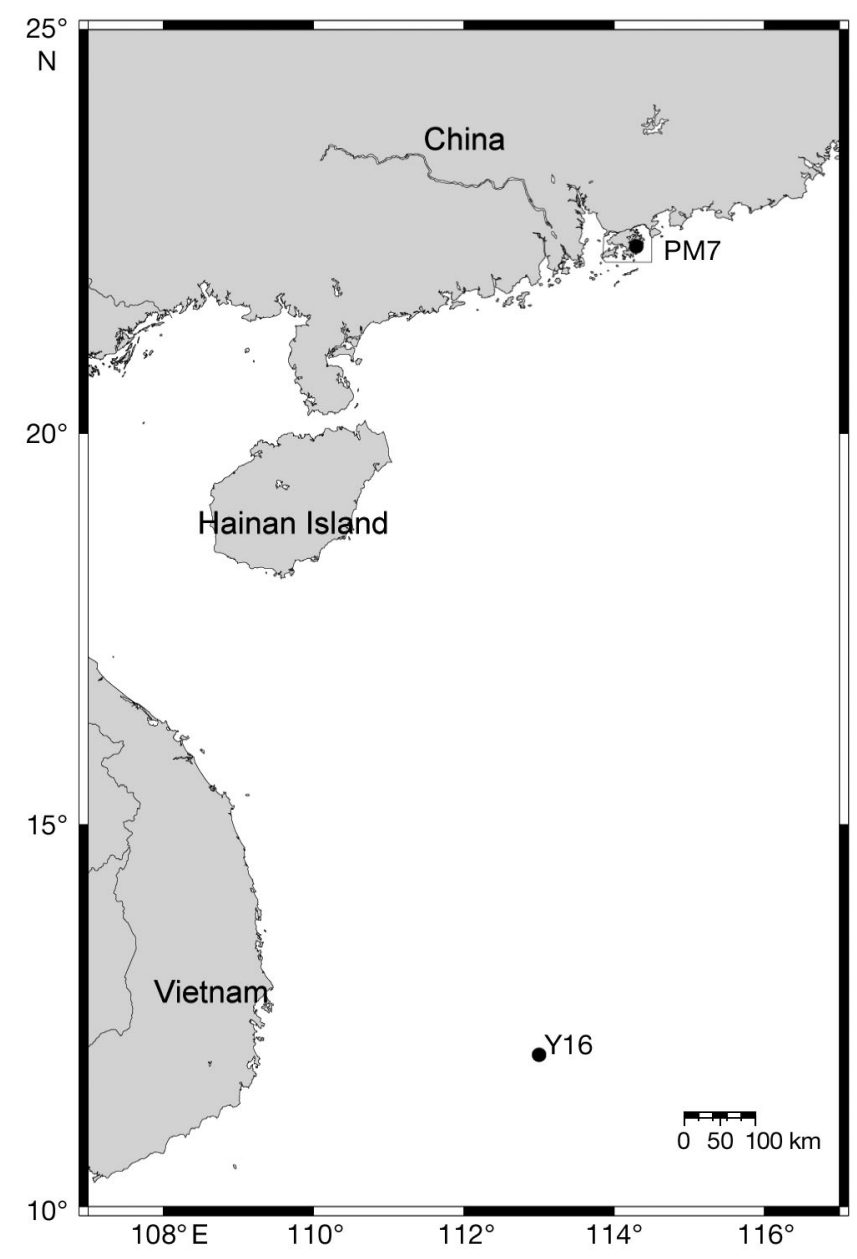

Fig. 1. Two sampling locations: coastal Stn PM7 (east of Hong Kong) and oligotrophic Stn Y16 (South China Sea)

(2009b). Briefly, seawater was collected from the surface and was processed immediately after sampling. Particle-free seawater (FSW) filtered through a $0.2 \mu \mathrm{m}$ filter capsule (Pall Corporation) was mixed with whole seawater (WSW) at several different proportions in 1.21 polycarbonate bottles. Three different WSW samples were prepared by using 3 meshes of different pore sizes $(200 \mu \mathrm{m}, 20 \mu \mathrm{m}, 5 \mu \mathrm{m})$ to prescreen the seawater. All incubation bottles, tubings, and carboys were washed with $10 \%$ (vol/vol) $\mathrm{HCl}$ and thoroughly rinsed with distilled water before each experiment. For the $200 \mu \mathrm{m}$ treatment, the fractions of WSW to the total volume were $6,27,51,73$, and $100 \%$, respectively. For $20 \mu \mathrm{m}$ and $5 \mu \mathrm{m}$ prescreened treatments, 3 or 4 dilution gradients were used. Duplicate bottles were prepared for each dilution gradient in the 3 treatments. All the bottles were enriched with nutrients (final concentrations: $10 \mu \mathrm{M} \mathrm{NaNO}_{3}$ and $1 \mu \mathrm{M} \mathrm{KH}_{2} \mathrm{PO}_{4}$ for the coastal and $0.5 \mu \mathrm{M} \mathrm{NH} \mathrm{Nl}_{4} \mathrm{Cl} 0.03 \mu \mathrm{M} \mathrm{KH_{2 }} \mathrm{PO}_{4}, 1 \mathrm{nM} \mathrm{FeCl}$, $0.1 \mathrm{nM} \mathrm{MnCl}_{2}$ for the SCS station) to promote constant phytoplankton growth. Another two $100 \%$ bottles 
without nutrient addition served as no-nutrient controls for all three $200 \mu \mathrm{m}, 20 \mu \mathrm{m}$, and $5 \mu \mathrm{m}$ prescreened treatments. Another 2 bottles filled with unfiltered seawater were sacrificed for initial samplings, including chlorophyll a (chl a), FCM, nanoplankton, and microzooplankton samples. All the bottles were tightly capped, incubated for $24 \mathrm{~h}$, and cooled by running seawater under $\sim 50 \%$ surface irradiance. The bottles were gently mixed by hand once or twice during the incubation. After incubation, FCM subsamples were taken from each bottle for all treatments. For one experiment conducted in June, microplankton samples were also taken from the 2 control bottles of the $200 \mu \mathrm{m}$ prescreened treatments, and nanoplankton samples were taken from control bottles of the $200 \mu \mathrm{m}$, $20 \mu \mathrm{m}$, and $5 \mu \mathrm{m}$ prescreened treatments.

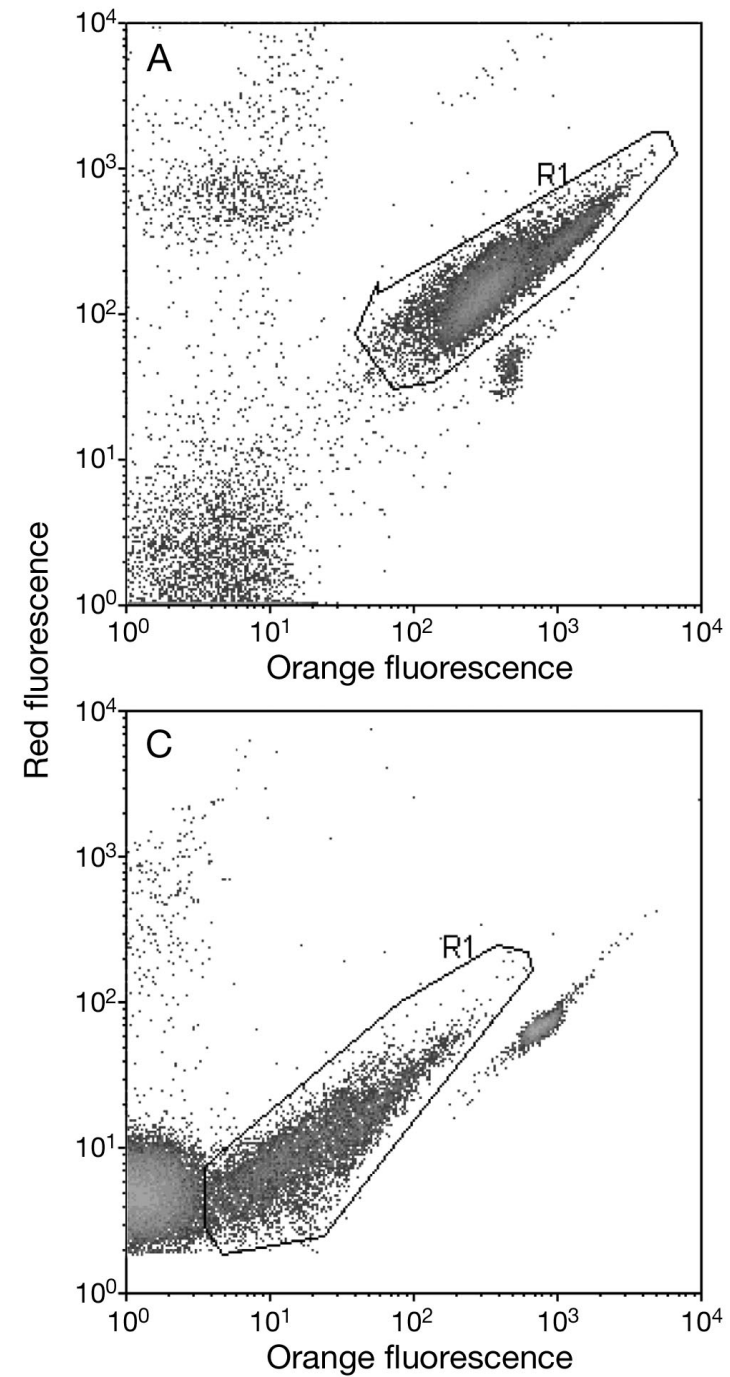

For chl a analysis, seawater was filtered onto GF/F glass fiber filters (Whatman) under low vacuum. The filters were extracted in $10 \mathrm{ml} 90 \%$ acetone at $4^{\circ} \mathrm{C}$ in the dark for $20 \mathrm{~h}$, and chl a concentrations were determined with a Turner designed fluorometer (Model \#040) using the acidification method (Strickland \& Parsons 1972). FCM samples collected from Hong Kong coastal waters were fixed with $0.2 \%$ buffered paraformaldehyde and analyzed on an Epics XL cytometer (Beckman Coulter). FCM samples collected in the SCS were analyzed on a BD FACSCalibur cytometer (Becton Dickson). Different populations of ultraphytoplankton (Prochlorococcus [PRO], Synechococcus [SYN], PP, and NP) were distinguished on the basis of side scattering, orange and red fluorescence (Olson et al. 1993; Fig. 2). PRO was detected
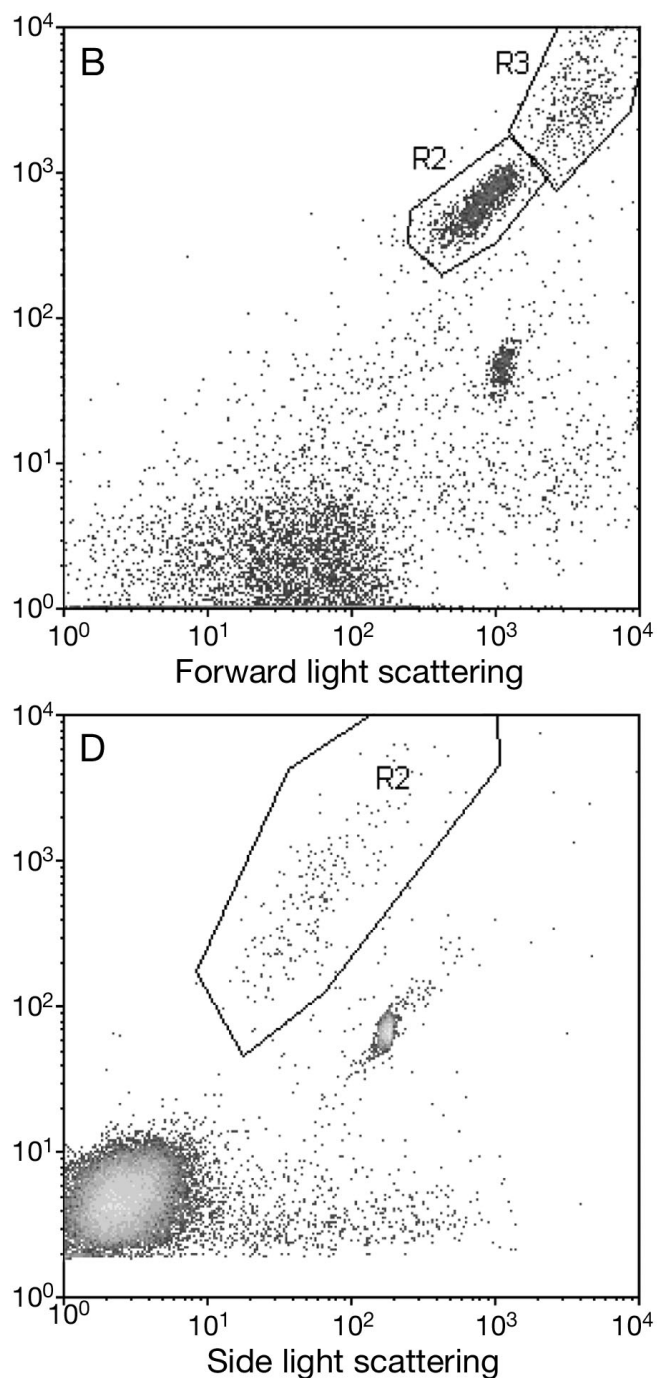

Fig. 2. (A,B) Cytograms of an unstained sample collected in June 2007 at Stn PM7, showing the positions of Synechococcus (R1), picophytoeukaryotes (R2), and nanophytoeukaryotes (R3). The cells of Synechococcus (R1) have been gated out in (B). (C,D) Cytograms of an unstained sample collected in September 2007 at Stn Y16, showing the positions of Synechococcus (R1), picophytoeukaryotes (R2), and Prochlorococcus (lower left). The cells of Synechococcus (R1) have been gated out in (D) 
only at the SCS station. Yellow-green fluorescent beads ( $1 \mu \mathrm{m}$, Polysciences) were added to the samples as an internal standard. For counting heterotrophic bacteria, SYBR Green I was added to the samples at the final concentration of $0.01 \%$ (Molecular Probes) (Marie et al. 1997). The flow rates were $\sim 1 \mu \mathrm{s}^{-1}$ for picophytoplankton and $0.25 \mu \mathrm{s}^{-1}$ for heterotrophic bacteria. The exact flow rate was calibrated by weighing a tube filled with distilled water before and after running for certain time intervals, and the flow rate was estimated as the slope of a linear regression curve between time lags and weight differences. The cytograms were analyzed by the free software WINMDI 2.9 (Joseph Trotter). The equivalent spherical diameters (ESDs) of the plankton were estimated from forward light scattering (FS) normalized to $1 \mu \mathrm{m}$ beads, using empirically determined equations according to Gin (1996). The biovolumes of the phytoplankton were estimated on the basis of the ESDs.

To enumerate the abundance of HNFs, $20 \mathrm{ml}$ subsamples fixed by $1 \%$ buffered paraformaldehyde were stained by 4',6-diamidino-2-phenylindole (DAPI) and gently filtered onto $1 \mu \mathrm{m}$ polycarbonate plain membrane filters. The filters were immediately mounted onto a glass slide after a quick breath. The slides were inspected using an epifluorescence microscope at the magnification of $1000 \times$ under UV excitation, and the number of HNFs were counted on 1 transect across the center of the membrane. At least 200 cells were counted for each sample. Autotrophic and heterotrophic flagellates were distinguished on the basis of the presence of red fluorescence under blue light excitation. The biomass of HNFs was estimated assuming an average ESD of $3 \mu \mathrm{m}$ and a carbon-to-volume ratio of 0.22 pg $C \mu \mathrm{m}^{-3}$ (Garrison et al. 2000). The HNFs were assumed to represent the grazers smaller than $5 \mu \mathrm{m}$.

Samples for enumeration of ciliates were fixed with $5 \%$ acidic Lugol's solution, and the ciliates were counted and sized by the Utermöhl method at $200 \times$ magnification with an Olympus IX51 inverted microscope as described by Chen et al. (2009b). Carbon content of ciliates was estimated using the conversion factor $0.19 \mathrm{pg} \mathrm{C}$ $\mathrm{mm}^{-3}$ (Putt \& Stoecker 1989). We calculated total numerical abundances and biomass for small $(<20 \mu \mathrm{m})$ and large $(>20 \mu \mathrm{m})$ ciliates to estimate the grazer biomass between 5 and $20 \mu \mathrm{m}$ and $>20 \mu \mathrm{m}$, respectively. All ciliates were $>5 \mu \mathrm{m}$.

Intrinsic growth rate $\left(\mu_{n}\right)$ and microzooplankton grazing rate $(m)$ of phytoplankton are derived by linear regression of net growth rates versus dilution factors (proportions of unfil- tered seawater). In situ phytoplankton instantaneous growth rate $\left(\mu_{0}\right)$ equals $m$ plus net growth rate of phytoplankton in control bottles without nutrient addition (Landry 1993). When grazing saturation occurs (Gallegos 1989), $m$ equals to $\mu_{n}$ minus the average growth rate in the $100 \%$ treatments with nutrient addition (Strom et al. 2007). Macronutrients (nitrate, nitrite, ammonia, phosphate, and silicate) were analyzed with a SKALAR auto-analyzer. Temperature and salinity were recorded using a YSI 6600 multi-probe sensor (YSI) in Hong Kong coastal waters and using a Conductivity-Temperature-Depth (CTD) sensor in open ocean waters.

\section{RESULTS}

\section{Ambient physical and chemical parameters and plankton compositions}

The temperature, salinity, nutrients, chlorophyll, and bacterial abundances in the 6 experiments are shown in Table 1. Notably, nitrate and phosphate concentrations were the highest in December (winter), followed by those in June when it rained before the sampling. Silicate concentrations were generally high, precluding the possibility of silicate limitation on phytoplankton growth. The tropical station in SCS, Y16, was extremely oligotrophic in terms of nutrient and chl a concentrations. Bacterial abundances at Stn Y16 were also lower than those at PM7 (Table 1), by an order of magnitude at maximum.

At PM7, 3 groups of ultraphytoplankton including SYN, PP, and NP could be clearly distinguished on the cytograms (Fig. 2A,B) in April, June, and December. In May and July, PP could not be clearly defined. At Stn Y16 in the oligotrophic SCS, PRO could also be detected together with SYN and PP (Fig. 2C,D). Data on NP are not presented owing to low abundances at Y16. SYN numerically dominated phytoplankton assemblage from April to July at PM7, while it was out-

Table 1. Temperature $\left(\mathrm{T}^{\circ} \mathrm{C}\right)$, salinity, and concentrations of ammonia $\left(\mathrm{NH}_{4}{ }^{+}, \mu \mathrm{mol}\right.$ $\left.\mathrm{l}^{-1}\right)$, nitrate and nitrite $\left(\mathrm{NO}_{3}{ }^{-}+\mathrm{NO}_{2}{ }^{-}, \mu \mathrm{mol} \mathrm{l}^{-1}\right)$, phosphate $\left(\mathrm{PO}_{4}{ }^{3-}, \mu \mathrm{mol} \mathrm{l}{ }^{-1}\right)$, silicate $\left(\mathrm{Si}, \mu \mathrm{mol} \mathrm{l^{-1 }}\right)$, chl a $\left(\mu \mathrm{g} \mathrm{l}^{-1}\right)$, and bacterial abundances (BA, $10^{5}$ cells $\mathrm{ml}^{-1}$ ) of the 6 experiments conducted in 2007. ND: no data

\begin{tabular}{|cccccccccc|}
\hline Stn & Date & $\mathrm{T}^{\circ} \mathrm{C}$ & Salinity & $\mathrm{NH}_{4}{ }^{+}$ & $\mathrm{NO}_{3}{ }^{-}+\mathrm{NO}_{2}{ }^{-}$ & $\mathrm{PO}_{4}{ }^{3-}$ & $\mathrm{Si}$ & $\mathrm{Chl} a$ & $\mathrm{BA}$ \\
\hline PM7 & 17 Apr & 23.2 & 37.0 & 2.33 & 0.31 & 0.06 & 5.06 & 0.60 & 4.11 \\
PM7 & 14 May & 25.9 & 34.0 & 0.17 & 0.15 & 0.06 & 0.92 & 1.03 & 8.45 \\
PM7 & 11 Jun & 26.3 & 32.6 & 3.03 & 1.89 & 0.12 & 15.18 & 1.91 & 18.7 \\
PM7 & 9 Jul & 30.6 & 27.0 & 0.13 & 0.08 & 0.01 & 22.24 & 1.20 & 26.7 \\
PM7 & 8 Dec & 19.8 & 31.6 & 1.61 & 9.43 & 1.05 & 20.38 & 1.84 & 11.9 \\
Y16 & 5 Sep & 29.5 & 32.3 & $\mathrm{ND}$ & $<0.2$ & 0.007 & 2.29 & 0.097 & 2.37 \\
\hline
\end{tabular}


numbered by eukaryotes in December (Fig. 3A). PRO was the numerical dominator at Stn Y16, followed by SYN and then PP (Fig. 3A). In comparison, although being much rarer, NP often dominated the ultraphytoplankton assemblage in terms of biovolume at PM7 except in July when SYN was extremely abundant (Fig. 3B). At Stn Y16, however, PRO was still the greatest contributor to total biovolume.

Initial abundances of HNFs ranged from 70 to 1040 cells $\mathrm{ml}^{-1}$ and were higher during the summer than other periods (Fig. 4A). Abundances of small ciliates $(<20 \mu \mathrm{m})$ were always higher than those of large ciliates $(>20 \mu \mathrm{m})$ (Fig. 4A), while the biomass of large ciliates was often higher than or comparable to that of small ones (Fig. 4B).

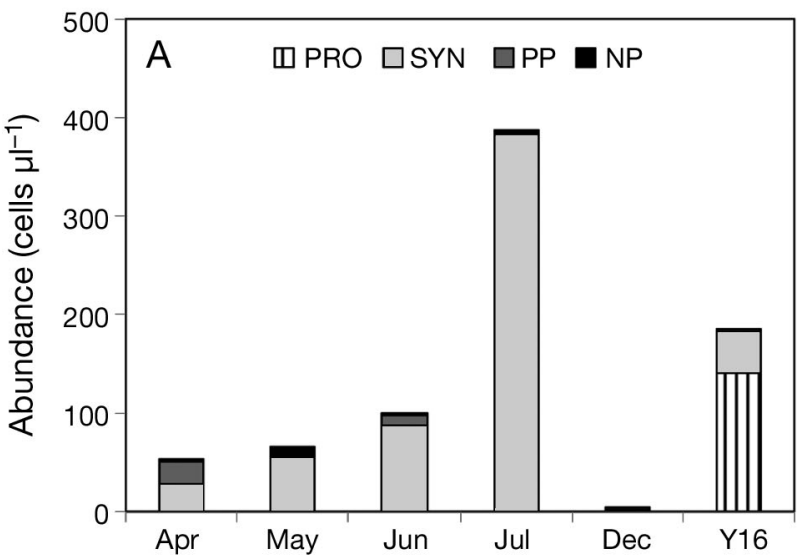

\section{Variations of microzooplankton grazing rates in different size-fractionated treatments}

An example of dilution plots of net growth rates of 3 groups of ultraphytoplankton in April in different dilution treatments is shown in Fig. 5, and the detailed growth and grazing rates $(m)$ are given in Table 2 . Grazing rates on ultraplankton in different sizefractionated treatments revealed some interesting but inconsistent results. Grazing rates on SYN $\left(m_{\text {SYN }}\right)$ were significantly higher in the $<5 \mu \mathrm{m}$ treatments than in the $<20 \mu \mathrm{m}$ treatments in 3 of 6 instances (Tables 2 \& $3)$. In other experiments, the differences were not significant. The $m_{\mathrm{SYN}}$ in the $<200 \mu \mathrm{m}$ treatments were always not significantly different from those in the

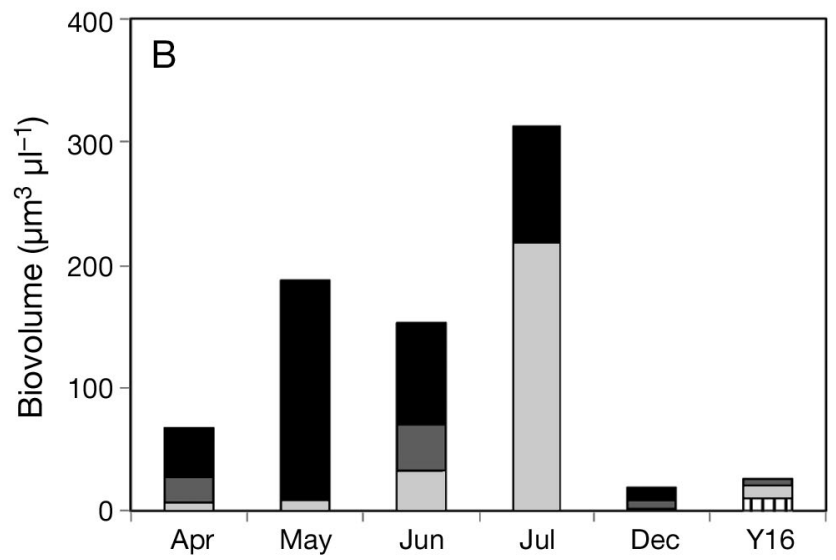

Fig. 3. (A) Abundances and (B) biovolumes of ultraphytoplankton of the 6 experiments. PRO = Prochlorococcus, SYN = Synechococcus, $\mathrm{PP}=$ picophytoeukaryotes, $\mathrm{NP}=$ nanophytoeukaryotes
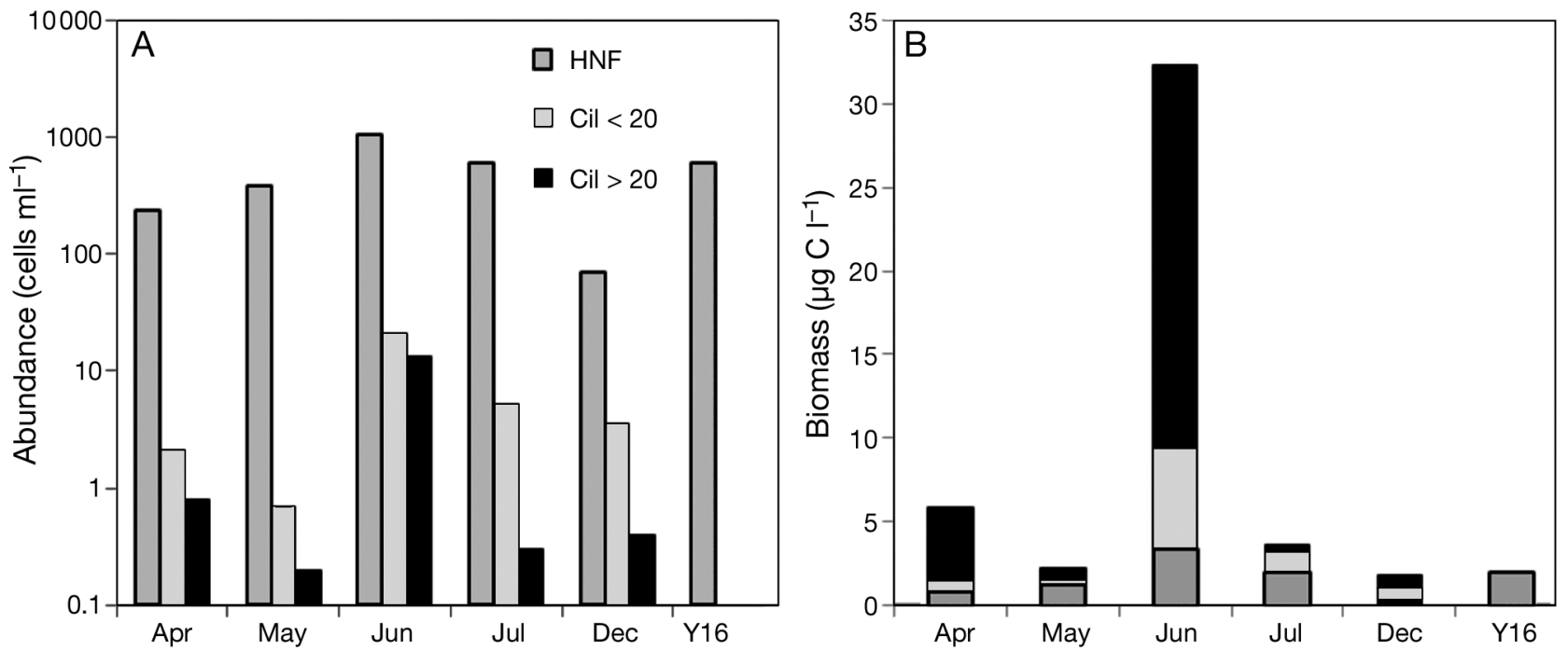

Fig. 4. (A) Abundances and (B) biomasses of heterotrophic nanoflagellates (HNFs), small ciliates $(<20 \mu \mathrm{m})$, and large ciliates $(>20 \mu \mathrm{m})$ in initial waters of each experiment. Ciliates were not counted at Y16 


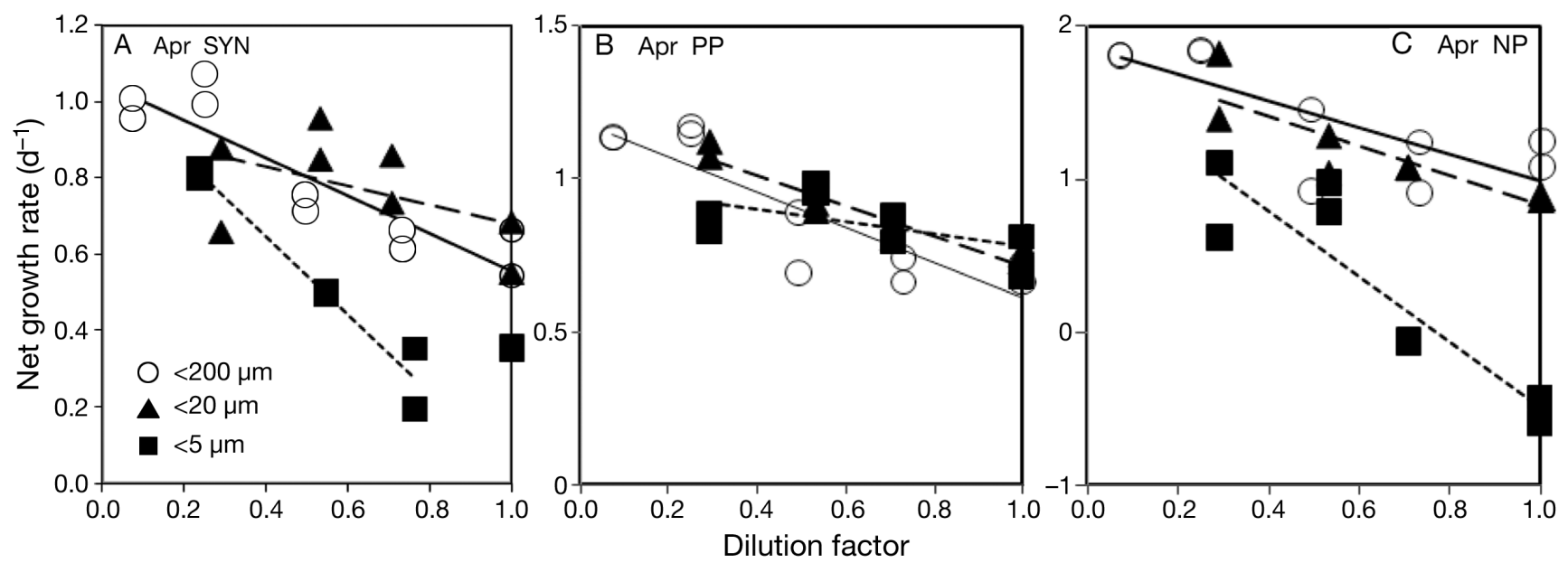

Fig. 5. Net growth rates of different ultraplankton components versus dilution factors in 3 different treatments in April. (A) Synechococcus (SYN), (B) picophytoeukaryotes (PP), (C) nanophytoeukaryotes (NP)

$<20 \mu \mathrm{m}$ treatments (Table 3). Among the 4 experiments in which PP appeared, grazing rates in the $<20 \mu \mathrm{m}$ treatments were significantly higher than those in the $<5 \mu \mathrm{m}$ treatments in April at PM7 and at Y16 (Table 3 ), and the growth rates $\left(\mu_{n}\right)$ of PP also differed greatly in the 2 treatments. In June, microzooplankton grazing rates on PP $\left(m_{\mathrm{PP}}\right)$ in the $<200 \mu \mathrm{m}$ treatments were significantly higher than those in the $<20 \mu \mathrm{m}$ treatments. For NP, $m_{\mathrm{NP}}$ in the $<20 \mu \mathrm{m}$ treatments were significantly lower than in the $<5 \mu \mathrm{m}$ treatments in April.

Often $m_{\text {PP }}$ reached a 1:1 relationship with $m_{\text {SYN }}$ (Pearson $\mathrm{r}=0.87, \mathrm{n}=12, \mathrm{p}<0.001$ ) (Fig. 6A), while $m_{\mathrm{NP}}$ were not correlated with $m_{\text {SYN }}$ or $m_{\mathrm{PP}}(\mathrm{p}>0.05)$ (Fig. 6B).

Most estimates of growth $\left(\mu_{0}\right)$ and grazing rates of SYN and PP, but not NP, were close to 1:1 (Fig. 7). The $m_{\text {SYN }}$ and $m_{\text {PP }}$ in the $<200 \mu \mathrm{m},<20 \mu \mathrm{m}$, and $<5 \mu \mathrm{m}$ treatments were all correlated with initial HNF biomasses ( $\mathrm{p}<0.05, \mathrm{n}=6$ and 4 for SYN and PP, respectively), but not related to the summed biomass of HNF and ciliates ( $p>0.05 ;$ Fig. 8). However, $m_{N P}$ were not related to initial HNF biomass, summed biomass of HNF and small ciliates $(<20 \mu \mathrm{m})$, or summed biomass of HNF and all ciliates in any treatments $(p>0.05$; Fig. 8A).

In the June experiment in which we examined the growth response of HNFs and ciliates in control bottles, the net growth rates of HNFs were the highest $\left(0.79 \mathrm{~d}^{-1}\right)$ in the $<5 \mu \mathrm{m}$ treatments but did not differ greatly between the $<200 \mu \mathrm{m}\left(0.16 \mathrm{~d}^{-1}\right)$ and the $<20 \mu \mathrm{m}$ treatments $\left(0.02 \mathrm{~d}^{-1}\right)$, as the error range between duplicates was around $0.1 \mathrm{~d}^{-1}$. Ciliates, however, showed a negative net growth in the $<200 \mu \mathrm{m}$ control bottles. On average, the net growth rates of large $(>20 \mu \mathrm{m})$ and small $(<20 \mu \mathrm{m})$ ciliates were $-0.38 \mathrm{~d}^{-1}$ and $-0.50 \mathrm{~d}^{-1}$, respectively.

\section{DISCUSSION}

A salient pattern from our data is that ultraphytoplankton cells are mostly grazed by HNFs, supporting previous observations from size-fractionated experiments (Wikner \& Hagstrom 1988, Calbet et al. 2001, Chen et al. 2009a). Although the biomass of heterotrophic flagellates contributed to only a small proportion of total microzooplankton biomass, grazing rates on ultraphytoplankton cells $<5 \mu \mathrm{m}$ were usually comparable or higher in the $<5 \mu \mathrm{m}$ treatment than in the $<20 \mu \mathrm{m}$ or $<200 \mu \mathrm{m}$ treatment (Table 2), implying that larger grazers (mostly ciliates) had a negligible grazing effect on the picophytoplankton in situ (Caron et al. 1991, Reckermann \& Veldhuis 1997, Chen et al. 2009a). The good correlation between $m_{\mathrm{SYN}}$ and $m_{\mathrm{PP}}$ and HNF biomasses suggests that SYN and PP were probably eaten by the same grazers, as the sizes of SYN and PP were similar (Martin et al. 2008). We did not expect to see that $m_{\mathrm{PP}}$ were lower in the $<5 \mu \mathrm{m}$ treatments than in the $<20 \mu \mathrm{m}$ treatments in 2 experiments. We think the cells were probably impaired by filtration during the experimental manipulation, as the growth rates were also negatively affected. Further, the close 1:1 relationships between growth and grazing rates of picoplankton (Fig. 8) suggest that grazing by HNFs can account for most losses of SYN and PP.

Combining the size-fractionation method with the dilution technique provides a robust way to estimate the grazing rates of different grazer assemblages on phytoplankton (Calbet 2008). Compared with monitoring the changes of prey surrogates (Vaque et al. 2008), an advantage of this approach is the ability to monitor the grazing rates on several phytoplankton groups simultaneously. However, to be sensitive enough to detect significant differences among differ- 
Table 2. Growth rates with nutrient addition $\left(\mu_{\mathrm{n}}, \mathrm{d}^{-1}\right)$, grazing rates $\left(m, \mathrm{~d}^{-1}\right)$, and growth rates with no nutrient addition $\left(\mu_{0}\right.$, $\left.\mathrm{d}^{-1}\right)$ of Synechococcus, picophytoeukaryotes, and nanophytoeukaryotes. The numbers in parentheses are the $95 \%$ confidence intervals for the estimated parameters using linear regression. The numbers in italics indicate that nonlinearity due to grazing saturation has occurred

\begin{tabular}{|c|c|c|c|c|c|c|c|}
\hline Experiment & $\begin{array}{l}\text { Treatment } \\
\text { ( } \mu \mathrm{m} \text { pore size) }\end{array}$ & $\mu_{\mathrm{n}}$ & $m$ & $\mu_{0}$ & $\mathrm{r}^{2}$ & $\mathrm{n}$ & $\mathrm{p}$ \\
\hline \multicolumn{8}{|c|}{ Synechococcus } \\
\hline \multirow[t]{3}{*}{ Apr } & $<200$ & $1.05(0.94,1.16)$ & $0.50(0.31,0.69)$ & 1.06 & 0.82 & 10 & $<0.001$ \\
\hline & $<20$ & $0.93(0.64,1.23)$ & $0.25(-0.17,0.68)$ & 0.77 & 0.26 & 8 & $>0.05$ \\
\hline & $<5$ & $1.06(0.89,1.23)$ & $0.71(0.54,0.88)$ & 0.9 & 0.96 & 6 & 0.001 \\
\hline \multirow[t]{3}{*}{ May } & $<200$ & $0.95(0.80,1.09)$ & $0.77(0.47,1.09)$ & -0.04 & 0.86 & 8 & 0.001 \\
\hline & $<20$ & $0.78(0.43,1.13)$ & $0.66(0.15,1.17)$ & 0.51 & 0.63 & 8 & $<0.05$ \\
\hline & $<5$ & $0.35(0.13,0.57)$ & $0.31(-0.01,0.62)$ & 0.35 & 0.49 & 8 & $>0.05$ \\
\hline \multirow[t]{3}{*}{ Jun } & $<200$ & $2.51(2.09,2.93)$ & $2.30(1.60,3.00)$ & 2.39 & 0.88 & 10 & $<0.001$ \\
\hline & $<20$ & $2.49(2.30,2.68)$ & $1.70(1.41,2.00)$ & 2.10 & 0.99 & 6 & $<0.001$ \\
\hline & $<5$ & $2.24(1.89,2.60)$ & $2.44(1.88,3.02)$ & 2.23 & 0.97 & 6 & $<0.001$ \\
\hline \multirow[t]{3}{*}{ Jul } & $<200$ & $1.42(1.18,1.65)$ & $1.32(0.93,1.71)$ & 1.43 & 0.89 & 10 & $<0.001$ \\
\hline & $<20$ & $1.12(0.85,1.40)$ & $1.54(1.11,1.97)$ & 1.50 & 0.93 & 8 & $<0.001$ \\
\hline & $<5$ & $0.90(0.68,1.12)$ & $1.00(0.67,1.34)$ & 1.15 & 0.9 & 8 & $<0.001$ \\
\hline \multirow[t]{3}{*}{ Dec } & $<200$ & $1.55(1.50,1.59)$ & $0.30(0.23,0.37)$ & 1.65 & 0.92 & 10 & $<0.001$ \\
\hline & $<20$ & $1.42(1.31,1.53)$ & $0.29(0.12,0.47)$ & 1.41 & 0.85 & 6 & 0.01 \\
\hline & $<5$ & $1.25(1.06,1.44)$ & $0.38(0.08,0.68)$ & 1.24 & 0.76 & 6 & 0.02 \\
\hline \multirow[t]{3}{*}{ Y16 } & $<200$ & $1.50(1.31,1.70)$ & $0.63(0.31,0.95)$ & 0.78 & 0.71 & 10 & 0.002 \\
\hline & $<20$ & $0.74(0.47,1.02)$ & $0.59(0.16,1.03)$ & 0.8 & 0.78 & 6 & 0.02 \\
\hline & $<5$ & $1.08(1.02,1.15)$ & $1.10(0.99,1.21)$ & 1.03 & 0.99 & 6 & $<0.001$ \\
\hline \multirow[t]{3}{*}{ Y16-PRO } & $<200$ & $0.47(0.39,0.56)$ & $0.47(0.33,0.62)$ & 0.39 & 0.87 & 10 & $<0.001$ \\
\hline & $<20$ & $0.62(0.47,0.77)$ & $0.58(0.34,0.81)$ & 0.51 & 0.92 & 6 & 0.003 \\
\hline & $<5$ & $0.66(0.56,0.77)$ & $0.68(0.52,0.85)$ & 0.62 & 0.97 & 6 & $<0.001$ \\
\hline \multicolumn{8}{|c|}{ Picophytoeukaryotes } \\
\hline \multirow{3}{*}{ Apr } & $<200$ & $1.19(1.04,1.34)$ & $0.57(0.33,0.82)$ & 0.84 & 0.79 & 10 & 0.001 \\
\hline & $<20$ & $1.21(1.11,1.30)$ & $0.49(0.36,0.63)$ & 1.06 & 0.92 & 8 & $<0.001$ \\
\hline & $<5$ & $0.98(0.78,1.18)$ & $0.2(-0.09,0.49)$ & 0.29 & 0.33 & 8 & $>0.05$ \\
\hline \multirow[t]{3}{*}{ Jun } & $<200$ & $2.48(2.32,2.62)$ & $2.18(1.93,2.42)$ & 2.10 & 0.98 & 10 & $<0.001$ \\
\hline & $<20$ & $2.10(1.78,2.49)$ & $1.70(1.14,2.27)$ & 1.76 & 0.96 & 6 & 0.001 \\
\hline & $<5$ & $1.87(1.61,2.14)$ & $2.21(1.79,2.63)$ & 1.50 & 0.98 & 6 & $<0.001$ \\
\hline \multirow[t]{3}{*}{ Dec } & $<200$ & $2.22(2.12,2.33)$ & $0.37(0.20,0.54)$ & 2.34 & 0.76 & 10 & 0.001 \\
\hline & $<20$ & $0.71(0.38,1.04)$ & $-0.75(-1.23,-0.23)$ & 0.64 & 0.8 & 6 & 0.02 \\
\hline & $<5$ & $1.01(0.75,1.28)$ & $-0.04(-0.46,0.38)$ & 1.00 & 0.02 & 6 & $>0.05$ \\
\hline \multirow[t]{3}{*}{ Y16 } & $<200$ & $1.12(0.74,1.51)$ & $0.61(-0.02,1.24)$ & 1.15 & 0.39 & 10 & $>0.05$ \\
\hline & $<20$ & $0.99(0.76,1.23)$ & $1.01(0.65,1.39)$ & 0.87 & 0.94 & 6 & 0.002 \\
\hline & $<5$ & $0.12(-0.01,0.26)$ & $0.24(0.03,0.47)$ & -0.05 & 0.7 & 6 & 0.034 \\
\hline \multicolumn{8}{|c|}{ Nanophytoeukaryotes } \\
\hline \multirow[t]{3}{*}{ Apr } & $<200$ & $1.86(1.52,2.20)$ & $0.88(0.31,1.44)$ & 1.40 & 0.62 & 10 & 0.007 \\
\hline & $<20$ & $1.81(1.41,2.21)$ & $0.98(0.40,1.56)$ & 1.60 & 0.74 & 8 & 0.006 \\
\hline & $<5$ & $1.66(0.96,2.36)$ & $2.15(1.13,3.18)$ & 2.14 & 0.82 & 8 & 0.002 \\
\hline \multirow[t]{3}{*}{ May } & $<200$ & $0.03(-0.09,0.16)$ & $0.05(-0.15,0.24)$ & -0.39 & 0.05 & 9 & $>0.05$ \\
\hline & $<20$ & $0.10(-0.98,1.19)$ & $1.06(-0.03,2.13)$ & 0.25 & 0.85 & 4 & $>0.05$ \\
\hline & $<5$ & $-0.13(-0.63,0.38)$ & $0.66(-0.02,1.35)$ & -0.07 & 0.55 & 7 & $>0.05$ \\
\hline \multirow[t]{3}{*}{ Jun } & $<200$ & $2.78(2.56,3.00)$ & $1.11(0.89,1.33)$ & 2.31 & 0.94 & 8 & $<0.001$ \\
\hline & $<20$ & $1.93(1.41,2.46)$ & $1.19(0.36,2.02)$ & 1.43 & 0.81 & 6 & 0.017 \\
\hline & $<5$ & $1.68(1.56,1.81)$ & $1.08(0.88,1.28)$ & 1.25 & 0.98 & 6 & $<0.001$ \\
\hline \multirow[t]{3}{*}{ Jul } & $<200$ & $1.81(1.66,1.97)$ & $0.88(0.72,1.04)$ & 1.27 & 0.97 & 8 & $<0.001$ \\
\hline & $<20$ & $1.57(1.33,1.82)$ & $1.14(0.76,1.52)$ & 1.06 & 0.9 & 8 & $<0.001$ \\
\hline & $<5$ & $1.30(0.66,1.95)$ & $0.42(-0.22,1.06)$ & 0.99 & 0.82 & 4 & $>0.05$ \\
\hline \multirow[t]{3}{*}{ Dec } & $<200$ & $2.03(1.94,2.13)$ & $0.41(0.26,0.57)$ & 1.98 & 0.83 & 10 & $<0.001$ \\
\hline & $<20$ & $1.40(1.18,1.62)$ & $0.57(0.23,0.92)$ & 1.55 & 0.84 & 6 & 0.01 \\
\hline & $<5$ & $1.62(1.46,1.78)$ & $0.47(0.22,0.73)$ & 1.55 & 0.87 & 6 & 0.007 \\
\hline
\end{tabular}

ent treatments, sufficient numbers of bottles need to be set up, which limits the routine use of this method (Kimmance et al. 2007). Nonetheless, the insignificant differences among different size-fractionated treat- ments may not be solely a methodology problem, but a result of grazer growth. If the first-order grazers (i.e. heterotrophic flagellates) are mostly bottom-up controlled, removal of the second-order grazers 
Table 3. Significance levels of differences in grazing rates in different treatments for each picophytoplankton group in each experiment. NS: not significant, ND: not determined, $\mathrm{PRO}=$ Prochlorococcus, $\mathrm{SYN}=$ Synechococcus, $\mathrm{PP}=$ picophytoeukaryotes, NP = nanophytoeukaryotes

\begin{tabular}{|lccc|}
\hline & 200 to $20 \mu \mathrm{m}$ & 200 to $5 \mu \mathrm{m}$ & 20 to $5 \mu \mathrm{m}$ \\
\hline Apr & & & \\
SYN & NS & $<0.01$ & 0.01 \\
PP & NS & $<0.05$ & $<0.05$ \\
NP & NS & $<0.05$ & $<0.05$ \\
May & & & \\
SYN & NS & $<0.05$ & NS \\
NP & $<0.01$ & $<0.05$ & NS \\
Jun & & & \\
SYN & NS & NS & $<0.05$ \\
PP & $<0.05$ & NS & NS \\
NP & NS & $<0.01$ & NS \\
Jul & & & \\
SYN & NS & NS & $<0.05$ \\
NP & $<0.01$ & NS & NS \\
Dec & & & \\
SYN & NS & NS & NS \\
PP & ND & ND & ND \\
NP & NS & NS & NS \\
Y16 & & & \\
PRO & NS & $<0.05$ & NS \\
SYN & NS & $<0.05$ & $<0.05$ \\
PP & NS & NS & \\
\hline
\end{tabular}

would have negligible effects on the growth of firstorder grazers. Conversely, if top-down controls on first-order grazers are important, removal of secondorder grazers would release first-order grazers from predation, and the grazing rate measured by the dilution technique would be higher than if second-order grazers were not removed (Calbet et al. 2008). As the incubation lasts only $1 \mathrm{~d}$, first-order grazers might not have enough time to develop enough biomass to impose significantly higher grazing rates even if their predators have been eliminated.

In other similar studies, it was often found that grazing rates on phytoplankton in $<20 \mu \mathrm{m}$ treatments usually did not differ much from those in $200 \mu \mathrm{m}$ treatments (Reckermann \& Veldhuis 1997, Lessard \& Murrell 1998). Reckermann \& Veldhuis (1997) found that growth and grazing rates of picophytoplankton in the $<10 \mu \mathrm{m}$ and $<3 \mu \mathrm{m}$ treatments were higher than in the $<200 \mu \mathrm{m}$ and $<20 \mu \mathrm{m}$ treatments. As inorganic nutrients were not added into the bottles to control phytoplankton growth rates in their study, a question remains whether the filtration process changed phytoplankton growth rates and the elevated grazing rates were just a positive response to phytoplankton growth rates, perhaps owing to improved food quality (Worden $\&$ Binder 2003). Therefore, nutrient addition in the dilution technique seems indispensable in order to meet the experimental assumptions (Landry 1993). Calbet et al. (2008) found appreciably higher grazing effects $(\mathrm{m} / \mu)$ on $<10 \mu \mathrm{m}$ chl $a$ in $<10 \mu \mathrm{m}$ treatments than in unprescreened treatments only during certain periods of spring. Kuipers \& White (2000) reported, however, that no noticeable differences in grazing rates on PRO existed among 200, 10, 5, and $3 \mu \mathrm{m}$ in lower euphotic layers.

Although not always significant, the occasional different grazing rates generated by different grazer assemblages separated by size, especially the grazing rates in the $<5 \mu \mathrm{m}$ treatments that were higher than those in the $<20 \mu \mathrm{m}$ treatments, reflect an existence of trophic cascading within the nanozooplankton range (Wikner \& Hagstrom 1988, Chen et al. 2009a, Zöllner et al. 2009). Assuming the clearance rates of the firstorder grazers do not change in the presence of their predators, the reduced grazing rates in the $<20 \mu \mathrm{m}$

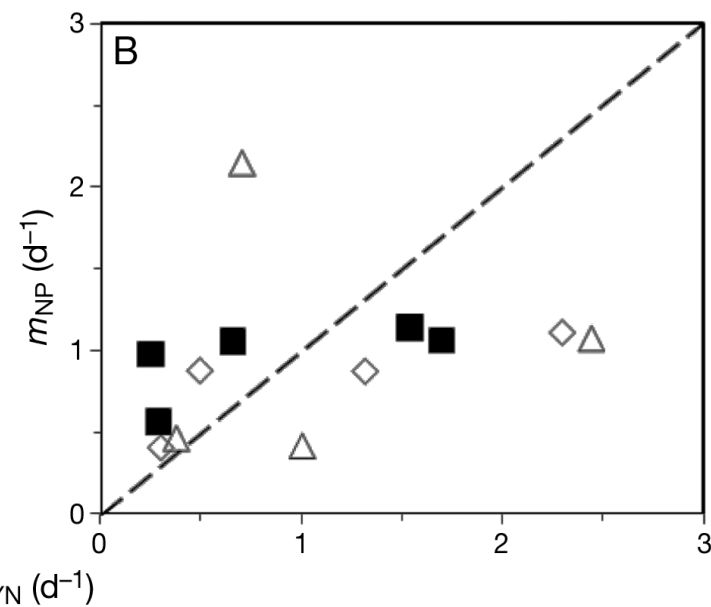

Fig. 6. Comparisons between grazing rates on (A) picophytoeukaryotes $\left(m_{\mathrm{PP}}\right)$ and (B) nanophytoeukaryotes $\left(m_{\mathrm{NP}}\right)$ and grazing rate on Synechococcus $\left(m_{\mathrm{SYN}}\right)$. The dashed lines represent a 1:1 relationship 

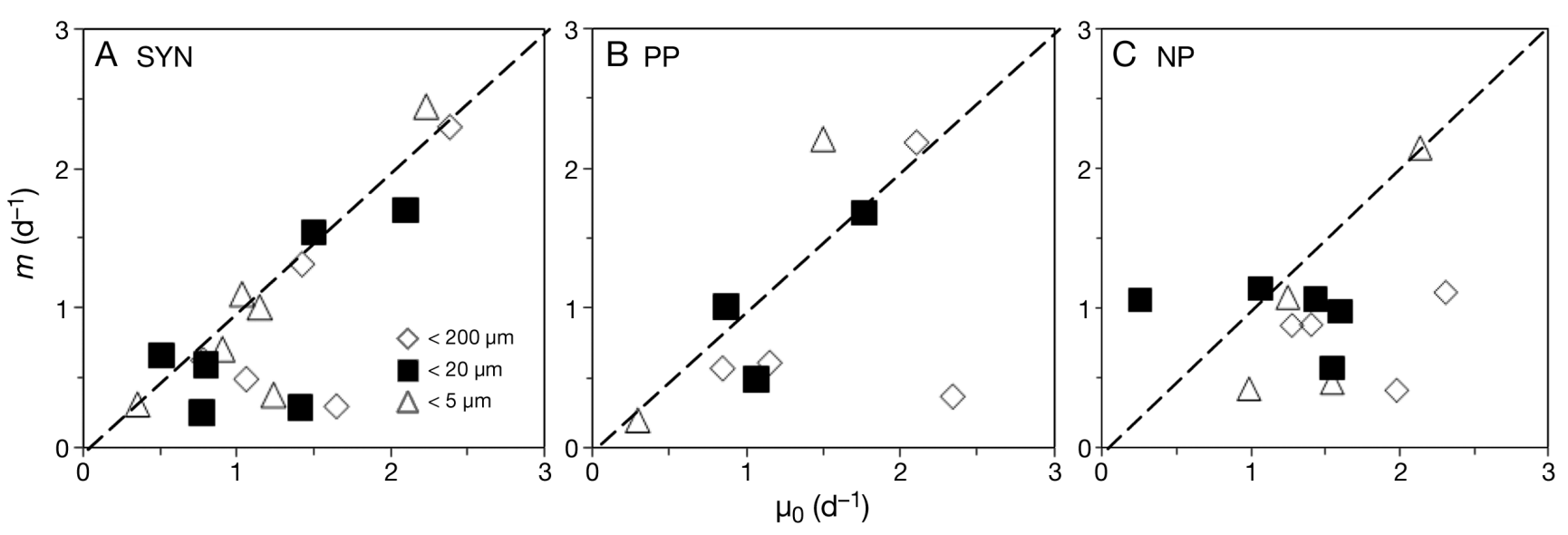

Fig. 7. Relationships between instantaneous growth rate $\left(\mu_{0}, \mathrm{~d}^{-1}\right)$ and microzooplankton grazing rates $\left(m_{1} \mathrm{~d}^{-1}\right)$ for $(\mathrm{A})$ Synechococcus (SYN), (B) picophytoeukaryotes (PP), (C) nanophytoeukaryotes (NP). The dashed line represents a 1:1 relationship
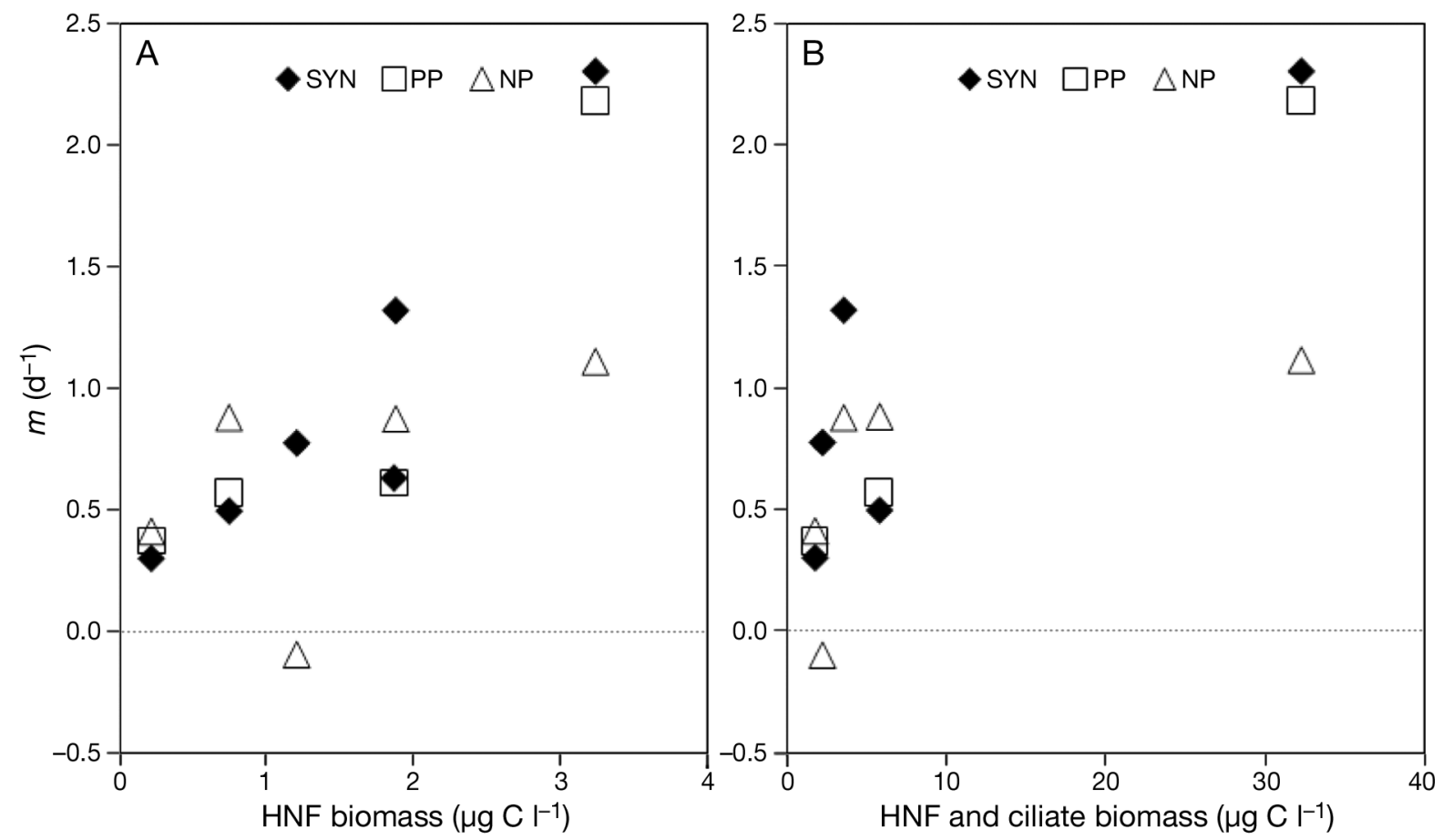

Fig. 8. Grazing mortality rates $\left(m, \mathrm{~d}^{-1}\right)$ of ultraphytoplankton in the $<200 \mu \mathrm{m}$ treatments versus (A) heterotrophic nanoflagellate (HNF) biomass and (B) the summed biomass of HNFs and ciliates

treatments should imply that a proportion of the firstorder grazers (i.e. HNFs) have been consumed by their predators (mainly ciliates) during the incubation, as suggested by the June data. In other words, the changes in microzooplankton grazing rates are basically a reflection of the growth of grazers in different treatments. Taking the experiment in June as an example, $m_{\mathrm{SYN}}$ in the $<20 \mu \mathrm{m}$ treatment was $70 \%$ of the $m_{\text {SYN }}$ in the $<5 \mu \mathrm{m}$ treatment, implying that $30 \%$ of the grazers feeding on SYN were consumed by their grazers in the $<20 \mu \mathrm{m}$ treatment during $24 \mathrm{~h}$ incubation. This is a conservative estimate since ciliates can also ingest SYN (Christaki et al. 1999). Based on microscopic counting, the average HNF abundance in the control bottles was 1590 cells $\mathrm{ml}^{-1}$ of the $<5 \mu \mathrm{m}$ treatment and 1050 cells ml ${ }^{-1}$ of the $<20 \mu \mathrm{m}$ treatment, supporting the above estimates. In the $<200 \mu \mathrm{m}$ treatment, as the second-order grazers were also controlled by the third-order grazers, the growth of first-order grazers (HNFs) was higher than in the $<20 \mu \mathrm{m}$ treatment, although at a smaller magnitude.

One potential artifact in the dilution technique is that due to the limiting food concentration in the diluted treatments, the growth rates of ciliates could be nega- 
tive (Dolan \& McKeon 2005). The growth of heterotrophic flagellates, on the contrary, can be positive in the diluted treatments, possibly because of the increases of large bacterioplankton abundances and the reduced abundances of ciliates (Agis et al. 2007). Assuming clearance rates of grazers do not change, the grazing rate on SYN and PP in the $<5 \mu \mathrm{m}$ treatments from which ciliates have been removed would be underestimated if the growth rates of HNFs are the same in diluted treatments as in undiluted treatments compared with if HNFs do not grow in diluted treatments but grow in undiluted treatments. For $<20 \mu \mathrm{m}$ or $<200 \mu \mathrm{m}$ treatments in which HNFs are grazed by ciliates in undiluted treatments, the grazing rate on SYN and PP would also be underestimated if HNFs grown in the diluted treatments are compared with HNFs not grown in diluted treatments but grown in undiluted treatments. Therefore, the final outcome (i.e. the differences of microzooplankton grazing rates between the $<5 \mu \mathrm{m}$ and the $<20 \mu \mathrm{m}$ or $<200 \mu \mathrm{m}$ treatments) appears irrelevant with this artifact.

Some inconsistent results from various experiments might also reflect the complexity of the marine microbial food web. The composition of the microzooplankton assemblage can have a considerable effect on the final outcomes. For example, in July when both SYN and heterotrophic bacteria were extremely abundant, most of the grazers, including the large ones $(>5 \mu \mathrm{m})$, may have been adapted to feed on such small particles. In such cases, removing the large nanozooplankton (5 to $20 \mu \mathrm{m}$ ) led to a reduction in grazing rate on SYN (Table 2). Also, the grazers of NP do not strictly fall into the 5 to $20 \mu \mathrm{m}$ category set artificially such that in some experiments (e.g. in April) the major grazers of NP were smaller than $5 \mu \mathrm{m}$. Estimates of $m_{\mathrm{SYN}}$ and $m_{\mathrm{NP}}$ do not correlate well in Fig. $7 \mathrm{C}$, implying that SYN and nanoeukaryotes were probably not eaten by the same group of grazers.

The feeding relationships among different sized grazers and their picoplankton prey within the microbial loop in this study, which represents mainly subtropical coastal waters, do not appear to differ from those in other studies in oligotrophic open oceans (Calbet \& Landry 1999, Calbet et al. 2001, Chen et al. 2009a). It is often suggested that food chains should be shorter in productive waters than in unproductive waters (Ryther 1969). Acknowledging that this is true, given that phytoplankton are often dominated by large diatoms, it may be safe to say that the microbial food web structure could be more or less similar in coastal and oceanic waters in that picoplankton need to pass through several trophic levels to be reached by mesoplankton, and significant amounts of carbon could be lost within the microbial food web (Landry \& Calbet 2004). Although the relative importance of the micro- bial food web is probably less significant in coastal waters than in open oceans, the active roles of the microbial food web and picoplankton in coastal waters have been increasingly recognized (Calbet 2001, Liu et al. 2004, Strom et al. 2007).

Acknowledgements. We sincerely thank H. Tseng for counting ciliate samples and M. Chen and L. Shek for assistance with nutrient analysis and field sampling. This study was supported by Hong Kong Research Grants Council (RGC) research grants HKUST661809 and HKUST661407 provided to H.L.

\section{LITERATURE CITED}

Agis M, Granda A, Dolan JR (2007) A cautionary note: examples of possible microbial community dynamics in dilution grazing experiments. J Exp Mar Biol Ecol 341:176-183

Armstrong RA (1994) Grazing limitation and nutrient limitation in marine ecosystems - steady-state solutions of an ecosystem model with multiple food-chains. Limnol Oceanogr 39:597-608

Calbet A (2001) Mesozooplankton grazing effect on primary production: a global comparative analysis in marine ecosystems. Limnol Oceanogr 46:1824-1830

Calbet A (2008) The trophic roles of microzooplankton in marine systems. ICES J Mar Sci 65:325-331

Calbet A, Landry MR (1999) Mesozooplankton influences on the microbial food web: direct and indirect trophic interactions in the oligotrophic open ocean. Limnol Oceanogr 44: $1370-1380$

Calbet A, Landry MR (2004) Phytoplankton growth, microzooplankton grazing, and carbon cycling in marine systems. Limnol Oceanogr 49:51-57

Calbet A, Landry MR, Nunnery S (2001) Bacteria-flagellate interactions in the microbial food web of the oligotrophic subtropical North Pacific. Aquat Microb Ecol 23:283-292

Calbet A, Trepat I, Almeda R, Salo V and others (2008) Impact of micro- and nanograzers on phytoplankton assessed by standard and size-fractionated dilution grazing experiments. Aquat Microb Ecol 50:145-156

> Caron DA, Lim EL, Miceli G, Waterbury JB, Valois FW (1991) Grazing and utilization of chroococcoid cyanobacteria and heterotrophic bacteria by protozoa in laboratory cultures and a coastal plankton community. Mar Ecol Prog Ser 76: 205-217

Chen B, Liu H, Wang Z (2009a) Trophic interactions within the microbial food web in the South China Sea revealed by size-fractionation method. J Exp Mar Biol Ecol 368: $59-66$

Chen B, Liu H, Landry MR, Chen M and others (2009b) Estuarine nutrient loading affects phytoplankton growth and microzooplankton grazing at two contrasting sites in Hong Kong coastal waters. Mar Ecol Prog Ser 379:77-90

Christaki U, Jacquet S, Dolan JR, Vaulot D, Rassoulzadegan F (1999) Growth and grazing on Prochlorococcus and Synechococcus by two marine ciliates. Limnol Oceanogr 44: $52-61$

Christaki U, Vazquez-Dominguez E, Courties C, Lebaron P (2005) Grazing impact of different heterotrophic nanoflagellates on eukaryotic (Ostreococcus tauri) and prokaryotic picoautotrophs (Prochlorococcus and Synechococcus). Environ Microbiol 7:1200-1210 
Dolan JR, McKeon K (2005) The reliability of grazing rate estimates from dilution experiments: Have we over-estimated rates of organic carbon consumption by microzooplankton? Ocean Sci 1:1-7

Frost BW (1972) Effects of size and concentration of food particles on the feeding behavior of the marine planktonic copepod Calanus pacificus. Limnol Oceanogr 17:805-815

Gallegos CL (1989) Microzooplankton grazing on phytoplankton in the Rhode River, Maryland: nonlinear feeding kinetics. Mar Ecol Prog Ser 57:23-33

Garrison DL, Gowing MM, Hughes MP, Campbell L and others (2000) Microbial food web structure in the Arabian Sea: a US JGOFS study. Deep-Sea Res II 47:1387-1422

Gin K (1996) Microbial size spectra from diverse marine ecosystems. PhD thesis, MIT, Woods Hole

Hansen B, Bjornsen PK, Hansen PJ (1994) The size ratio between planktonic predators and their prey. Limnol Oceanogr 39:395-403

Ichinotsuka D, Ueno H, Nakano S (2006) Relative importance of nanoflagellates and ciliates as consumers of bacteria in a coastal sea dominated by oligotrichous Strombidium and Strobilidium. Aquat Microb Ecol 42:139-147

> Jeong HJ, Seong KA, Du Yoo Y, Kim TH and others (2008) Feeding and grazing impact by small marine heterotrophic dinoflagellates on heterotrophic bacteria. J Eukaryot Microbiol 55:271-288

Kimmance SA, Wilson WH, Archer SD (2007) Modified dilution technique to estimate viral versus grazing mortality of phytoplankton: limitations associated with method insensitivity in natural waters. Aquat Microb Ecol 49:207-229

Kuipers BR, White HJ (2000) Prochlorophytes as secondary prey for heterotrophic nanoflagellates in the deep chlorophyll maximal layer of the (sub)tropical North Atlantic. Mar Ecol Prog Ser 204:53-63

Landry MR (1993) Estimating rates of growth and grazing mortality of phytoplankton by the dilution method. In: Kemp P, Sherr BF, Sherr EB, Cole JJ (eds) Handbook of methods in aquatic microbial ecology. Lewis Publishers, New York, p 715-722

Landry MR, Calbet A (2004) Microzooplankton production in the oceans. ICES J Mar Sci 61:501-507

Landry MR, Hassett RP (1982) Estimating the grazing impact of marine micro-zooplankton. Mar Biol 67:283-288

Landry MR, Brown SL, Rii YM, Selph KE, Bidigare RR, Yang EJ, Simmons MP (2008) Depth-stratified phytoplankton dynamics in Cyclone Opal, a subtropical mesoscale eddy. Deep-Sea Res II 55:1348-1359

> Lessard EJ, Murrell MC (1998) Microzooplankton herbivory and phytoplankton growth in the northwestern Sagasso Sea. Aquat Microb Ecol 16:173-188

Liu H, Dagg M, Campbell L, Urban-Rich J (2004) Picophytoplankton and bacterioplankton in the Mississippi River plume and its adjacent waters. Estuaries 27:147-156

Editorial responsibility: Hans Heinrich Janssen, Oldendorf/Luhe, Germany
Liu H, Dagg MJ, Strom S (2005) Grazing by the calanoid copepod Neocalanus cristatus on the microbial food web in the coastal Gulf of Alaska. J Plankton Res 27:647-662

> Marie D, Partensky F, Jacquet S, Vaulot D (1997) Enumeration and cell cycle analysis of natural populations of marine picoplankton by flow cytometry using the nucleic acid stain SYBR Green I. Appl Environ Microbiol 63:186-193

Martin AP, Zubkov MV, Fasham MJ, Burkill PH, Holland RJ (2008) Microbial spatial variability: An example from the Celtic Sea. Prog Oceanogr 76:443-465

Olson RJ, Zettler ER, DuRand MD (1993) Phytoplankton analysis using flow cytometry. In: Kemp P, Sherr BF, Sherr EB, Cole JJ (eds) Handbook of methods in aquatic microbial ecology. Lewis Publishers, New York, p 175-186

Putt M, Stoecker DK (1989) An experimentally determined carbon-volume ratio for marine oligotrichous ciliates from estuarine and coastal waters. Limnol Oceanogr 34:1097-1103

> Reckermann M, Veldhuis MJW (1997) Trophic interactions between picophytoplankton and micro- and nanozooplankton in the western Arabian Sea during the NE monsoon 1993. Aquat Microb Ecol 12:263-273

- Ryther JH (1969) Photosynthesis and fish production in sea. Science 166:72-76

Strickland JDH, Parsons TR (1972) A practical handbook of seawater analysis, 2nd edn. Bull Fish Res Board Can 167: 201-203

Strom SL, Macri EL, Olson MB (2007) Microzooplankton grazing in the coastal Gulf of Alaska: variations in top-down control of phytoplankton. Limnol Oceanogr 52:1480-1494

Unrein F, Massana R, Alonso-Saez L, Gasol JM (2007) Significant year-round effect of small mixotrophic flagellates on bacterioplankton in an oligotrophic coastal system. Limnol Oceanogr 52:456-469

Vaque D, Guadayol O, Peters F, Felipe J and others (2008) Seasonal changes in planktonic bacterivory rates under the ice-covered coastal Arctic Ocean. Limnol Oceanogr 53:2427-2438

Wikner J, Hagstrom A (1988) Evidence for a tightly coupled nanoplanktonic predator-prey link in regulating the bacterivores in the marine environment. Mar Ecol Prog Ser 50:137-145

Worden AZ, Binder BJ (2003) Application of dilution experiments for measuring growth and mortality rates among Prochlorococcus and Synechococcus populations in oligotrophic environments. Aquat Microb Ecol 30:159-174

Worden AZ, Nolan JK, Palenik B (2004) Assessing the dynamics and ecology of marine picophytoplankton: the importance of the eukaryotic component. Limnol Oceanogr 49: 168-179

Zöllner E, Hoppe HG, Sommer U, Jurgens K (2009) Effect of zooplankton-mediated trophic cascades on marine microbial food web components (bacteria, nanoflagellates, ciliates). Limnol Oceanogr 54:262-275

Submitted: June 29, 2009; Accepted: March 8, 2010 Proofs received from author(s): May 3, 2010 